\title{
The Le Corbusier Scandal, or, was Le Corbusier a Fascist?
}

\author{
Simone Brott \\ Creative Industries Faculty, Queensland University of Technology Australia \\ simone.brott@qut.edu.au
}

\begin{abstract}
In 2015 an essay by the architect Marc Perelman was printed in Le Monde claiming Le Corbusier was a fascist and that the French academy had whitewashed this from architectural history. The 2015 exhibition Le Corbusier: Mesures de l'homme, a major retrospective of the architect, held at the Centre Pompidou was adduced as evidence since it did not mention Le Corbusier's politics, despite three French books on Le Corbusier's fascism appearing in 2015, and the scandal that erupted around them. The letter was signed by myself, Zeev Sternhell, Xavier de Jarcy, Marc Perelman, and Daniel de Roulet; and reprinted in English by Verso in January 2017. The Fondation le Corbusier, who are unhappy with this turn of events, wrote to me asking me why I signed the letter. This essay will attempt to answer the question by evaluating the French quarrel, on both sides, and allegations about Le Corbusier's fascism.
\end{abstract}

\section{Keywords}

France - fascism - Le Corbusier - architecture - François Chaslin - Marc Perelman - Xavier de Jarcy

* I am grateful to Marc Perelman and François Chaslin who answered my questions in great detail, and to Xavier de Jarcy and Mark Antliff who read my essay and provided important insights and historical details.

(C) BROTT, $2017 \mid$ DOI 10.1163/22116257-00602003

This is an open access article distributed under the terms of the prevailing CC-BY-NC License at the time of publication. 
I wrote my book because I was shocked. I only understood in 2013 that LC was a fascist. As I say in the introduction, I couldn't sleep anymore. I thought he was a democrat, a liberal. I suddenly felt guilty and ashamed for having admired him since I was 16. Then I started to investigate, and Arnaud Dercelles told me there was an exhibition to be held in 2015. So I sent some extracts of my book to Hélène Monsacré, Zeev Sternhell's publisher, and that is how it started.

XAVIER DE JARCY ${ }^{1}$

The books of Chaslin, Jarcy and Perelman, because they appeared at the same time, were a 'thunderclap in a sky not too serene'; and the article that I wrote in Le Monde in May 2015 a genuine parricide. The organizers of the Beaubourg exhibition (2015) believed they were repeating the success of 1987. A tragic error. They believed and still believe in the existence of a plot by the three of us. My point of view is this: I don't think that Xavier's and my book disturbed them; it's Chaslin's book that annihilated them because François Chaslin comes from the seraglio - and there, he was a traitor; and he has been treated as such: cancellation of invitation[s], old friends or acquaintances have left him, and so on. It took him a long time to understand what was happening to him. He had put his finger where he should not have, in spite of his admiration for Le Corbusier. It was already too much for all the aficionados. Our three books have emerged as a return of the repressed (S. Freud).

MARC PERELMAN ${ }^{2}$

In April 2016 an open letter by the architect Marc Perelman was printed in Le Monde $^{3}$ claiming that Le Corbusier was a fascist and that the French academy

1 Email from Xavier de Jarcy to Simone Brott, 13 February 2017. English original.

2 Email from Marc Perelman to Simone Brott, 25 January 2017. English original.

3 Simone Brott, Marc Perelman, Zeev Sternhell, Xavier de Jarcy, Marc Perelman and Daniel de Roulet, 'L'idéal de Le Corbusier c'est la Caserne,' Le Monde, 22 November 2016. 
had whitewashed this from architectural history. The 2015 exhibition Le Corbusier: Mesures de l'homme, a major retrospective of the architect, held at the Centre Georges Pompidou was adduced as evidence since it did not mention Le Corbusier's politics. This was in spite of the synchronous appearance of three French language books on Le Corbusier's fascism that appeared at the time of the exhibition and the scandal that erupted in France around the books: Un Corbusier by François Chaslin, architect, professor, and writer for Le Monde and Nouvel Observateur; Le Corbusier, un fascisme français by Xavier de Jarcy, journalist at Télérama; and Le Corbusier: Une froide vision du monde by Marc Perelman, architect, and professor of aesthetics. ${ }^{4}$ The letter was signed by myself, Zeev Sternhell, Jarcy, Perelman, and Daniel de Roulet; and reappeared in English on Verso's website on 6 January 2017. ${ }^{5}$ The Fondation le Corbusier, who are unhappy with this turn of events, and with whom I have a friendship, wrote to me asking me why I signed the letter. I hope by this essay to answer the question. First, it's important to note that this is not an organized scholarly debate in France but a part personal and part media feud where one must inevitably take 'sides'. In response to scathing reviews of the Pompidou exhibition in Le Monde and the Telegraph, the Beaubourg gallery and Fondation announced a symposium Passés recomposés: Le Corbusier et l'architecture française 1929-1945 [The Reconstructed Past] in 2016 on Le Corbusier during the 1930s and Second World War, chaired by Rémi Baudoui (University of Geneva). ${ }^{6}$ Just after

4 François Chaslin, Un Corbusier: Fiction \& Cie (Paris: Seuil, 2015); Xavier de Jarcy, Le Corbusier, un fascisme français (Paris: Albin Michel, 2015); Marc Perelman, Le Corbusier: Une froide vision du monde: Essai (Paris: Michalon Éditeur, 2015). Another book Misère de l'espace moderne: La production de Le Corbusier et ses consequences (Agone, 2017) by Olivier Barancy has just been published.

5 Simone Brott, Marc Perelman, Zeev Sternhell, Xavier de Jarcy, Marc Perelman and Daniel de Roulet, “'Le Corbusier's Ideal is a Barracks", Verso, 6 January 2017.

6 Centre Pompidou, Colloque Le Corbusier: Passés Recomposés : Le Corbusier et L'architecture Française 1929-1945, https://www.centrepompidou.fr/cpv/ressource.action?param.id=FR_R -7010ea20-6aed-41c5-ad57-321f7e94de44\&param.idSource=FR_E-f44e4od5c732237 6e84e79ddogf623, accessed 27 October 2017. Avec Marie-Jeanne Dumont, Maïlis Favre, Jean-Noël Jeanneney, Mary Mcleod, Frédéric Migayrou, Antoine Picon, Josep Quetglas, Danièle Voldman, Dominique Barjot, Rémi Baudouï, Serge Berstein, Véronique Boone and Olivier Cinqualbre and Nader Vossoughian. While I was not able to attend the symposium, its intentions are declared in its mission statement 'The Symposium will also examine the symbolic function of the scapegoat that Le Corbusier has embodied in his lifetime to this day. Le Corbusier's life and career have been forever interpreted as the generic explanation of the totalitarian dimension of modernity and its substitutes.' Jarcy wrote to me: 'Marc and François went to the symposium, and I attended a few talks. Jean-Louis Cohen first explained LC was a kind of reactionary businessman when managing his brick factory before working 
the announcement, Perelman and Jarcy circulated a letter that stated: 'we fear that this event will lead to the suppression of the truth ... Le Corbusier will be [rendered] a humanist lost in a complex time, and his political activism ... a marginal place in his life [and] work.' Perelman and Jarcy would also protest they had been blocked from the symposium, which the Fondation would later deny. There are accusations on both sides.

This impasse is unfortunate, because when a scholar or intellectual becomes the object of critique or even accusation (rather than the historical figure and actual object of the research), there can be no historical distance in such a polemical, engagé stance. In this sense, the Le Corbusier controversy is reminiscent of the so-called Sternhell controversy. It also evokes what Henry Rousso called the 'Vichy Syndrome' a theory about France's inability to come to terms with its participation in the Vichy government of the Second World War, and the ways in which contemporary French culture and society continues to be haunted by this neurotic relationship with and distortion of fascist history. ${ }^{7}$ How does the Vichy malady haunt the world of Le Corbusier scholars? On the one hand, if you say Le Corbusier was a fascist, you become a traitor to the Fondation le Corbusier, and to the Franco-American architecture academy. On the other, if you do not consider Le Corbusier a fascist, you as an individual are implicated in the politics of apologia/denial charted by Rousso. These form the precise conditions that render the discussion of Le Corbusier's politics impassable in France at this moment.

This essay will evaluate the debate between the French writers, and 'the Corbusians', those inside the academy who oppose the books from the Fondation and Pompidou Centre to eminent scholars Mary Macleod and Jean-Louis

as an architect: he hated the trade-unionists who dared to go on strike. Then Cohen tried to demonstrate LC could also be considered a leftist, since he attracted some communists and socialists in the Thirties and tried to work for the Front Populaire government. But he also said: "In the Twenties Le Corbusier turned towards Italy." Baudoui said LC was an opportunist in a period of German occupation, that was very confused. Everybody had relations with everyone, no one was totally black or white etc .... According to Marc, Mary McLeod said Plans and Prélude were only syndicalist, not fascist, reviews. But of course, nobody discussed the question: was LC a fascist? . . Jean-Louis Cohen, Rémy Baudouï, Marie-Jeanne Dumont and Antoine Picon are members of the FLC. So they came to advocate the point of view of the Fondation.' Email from Xavier de Jarcy to Simone Brott, 13 February 2017.

7 Henry Rousso, The Vichy Syndrome: History and Memory in France since 1944 (Cambridge, Mass.: Harvard University Press, 1991). Vichy France was the name for the de facto French State following relocation to the town of Vichy, headed by Marshal Philippe Pétain, that collaborated with Hitler and established a Nazi occupation zone in France. Pétain instituted an authoritarian regime that destroyed the avant-garde status of Paris. Debbie Lackerstein, National Regeneration in Vichy France: Ideas and Policies, 1930-1944 (Farnham: Ashgate, 2012). 
Cohen (Columbia University, New York), and Antoine Picon. However, Chaslin does not fit into either camp, while he has had a major role, as he felt his book was unjustly conflated with Perelman and Jarcy's projects. Unlike those writers, Chaslin, a radical theorist against the academy, as well as being a journalist was also an insider, who, according to Perelman, is now considered a 'traitor'. The notion of two sides is subverted by Chaslin's suggestion that it was Cohen and Macleod who paved the way for the fascist understanding of Le Corbusier (both whom nonetheless contest the books). ${ }^{8}$ Perelman notes Macleod's manuscript on Le Corbusier's politics 'was never translated into French when she was very close to the FLC [Fondation le Corbusier]. Why? Because the FLC wanted to hide what could darken the face of Le Corbusier.'

My essay will adumbrate the historiography of Le Corbusier's politics, left and right, present the evidence and arguments from two of the books; respond to the variety of objections to the books; and address the question, why these books are appearing now, since material on Le Corbusier's fascism has been available since 1970. I include Chaslin's book-as the most significant, that dealt the largest blow to the Corbusians - and Perelman's book as a vastly different project - which charges Le Corbusier's oeuvre itself with fascism. Taken together, these books, their opponents, and the Le Corbusier scandal can be compared to the film Rashomon (1950) by Akira Kurosawa, which films four consecutive witnesses narrating the same story about a murder-in alternative self-serving ways. The murder, the assemblage called le fascisme français, certainly took place, the question is what was Le Corbusier's true relationship with it? This scandal is not only significant for Le Corbusier studies and France's heritage, but for the understanding of modern architecture and the architecture discipline more broadly - given Le Corbusier's mythic status in the field - he is considered by some to be the progenitor of modern architecture and urbanism.

The question is complicated by the fact that there was not one French fascism. As Robert Soucy wrote: 'a major weakness of French fascism was its failure to coalesce behind a single individual or a single party. Even during the Nazi Occupation, Jacques Doriot's Parti Populaire Français (PPF) and Marcel Deat's Rassemblement Nationale Populaire (RNP) failed to merge; the reasons are still vague, but the personal animosity and distrust between the leaders of the two formations was at times almost comic. ${ }^{9}$ Instead there was a multiplicity of fascist groups often in conflict with each other: from the Action Française

8 My Translation. Email from François Chaslin to Simone Brott, 28 January 2017. All translations from this message here on by Simone Brott.

9 Robert J Soucy, 'The Nature of Fascism in France,' Journal of Contemporary History 1, no. 1 (1966): 31 . 
and its transformation under Charles Maurras, to George Valois and Édouard Berth's Cahiers du Cercle Proudhon, Valois' Le Faisceau, Jacques Doriot's PPF, Marcel Deat's RNP, and the panoply of fascist newspapers and fascist intellectuals - who moved in and out of different fascist groups and publications that were in open conflict with each other, with some common denominators, but never a consensus. Mark Antliff provides an important insight to the question: what 'united' the French fascists was their indebtedness to the ideology of myth making of Georges Sorel, ${ }^{10}$ the father of philosophical fascism, and 'their aestheticized theory of violence'11 derived from Sorel that was a fundamental tenet of fascist philosophy in France. ${ }^{12}$ Le Corbusier's experiences in various fascist groups, and the fascist newspapers-for which he was not only a writer but a founding member and editor-and the important fascist group that formed around Le Corbusier's theory of urbanism, a group that would reassemble at Vichy-very much reflects this difficulty of naming the French fascist matrix, on the one hand, but importantly the dominant role of architecture and urbanism that unified it.

\section{Corbusian Historiography}

The accusation that Le Corbusier was a fascist was already a problem during his life. In a vexatious letter to his ex-friend Christian Zervos, the art historian, collector, curator, and critic, who founded the magazine Cahiers d'Art in Paris, Le Corbusier protests Zervos's fascist accusations against him in a campaign to persuade Zervos not to end the friendship. He vaunts his leftist affiliates, including

the National Union of intellectuals, the national Front of architects close to the Communist Party, ... the contact with architect Jean Nicolas, of the Communist Party, who had assisted in the Organization of the Congress CIAM in Paris in 1937 at the House of Culture ... Another sign of rallying to the side of the left, he announces to Zervos that he 'made a monthly page in the Volontés weekly,' where 'I have carte blanche.' Volontés was a political, economic, social and literary revue born of the Resistance

10 Mark Antliff, Avant-Garde Fascism: The Mobilization of Myth, Art, and Culture in France, 1909-1939 (Durham: Duke University Press, 2007), 247.

11 Antliff, Avant-Garde Fascism, 249.

12 They were in turn differentiated by their different interpretations of Sorel's philosophy. 
movement... Michel Collinet its editor-in-Chief, [was] a militant Trotskyite, close to [militant Socialist] Marceau Pivert. ${ }^{13}$

Zervos perceived Le Corbusier had sided with the Nazis by his post at Vichy, and according to Chaslin he 'militated against Le Corbusier in Communist networks and maligned him in his circles' with the result that Le Corbusier demanded Zervos 'discontinue his defamation' or suffer acute consequences. Le Corbusier mentions that Zervos had even threatened him with arrest by Joseph Darnand, head of the militia: 'and he issues more intimate, bitter and violent remarks to Zervos: "this should be enough to make you ashamed, if you feel the taste to feel ashamed from time to time! Because you like to hurt and disunite [those] around you".'14

While Le Corbusier and Zervos are no longer here to defend their positions, Le Corbusier mostly won this debate, at least until the 1980s. In left historiography, the architect's postwar works such as the Unité d'habitation [Housing unit], were often paralleled with the Phalanstère and ideal city of Charles Fourier as industrial socialist models of the city. Peter Serenyi wrote: 'Le Corbusier was heavily indebted to the thought of the 19th-century French utopians SaintSimon and Charles Fourier... There is a noteworthy resemblance between the concept of the unité and Fourier's phalanstery' ${ }^{\prime 15}$ Charles Maier's essay 'Between Taylorism and Technocracy: European Ideologies and the Vision of Industrial Productivity in the 1920s,' is another left example which never connected technocracy to French syndicalism and early French fascism that were built on the same foundation as the theories of technocracy and industrial production. ${ }^{16}$ Robert Fishman's Urban Utopias in the Twentieth Century (1977) continued this tradition of the socialist utopian Le Corbusier, notwithstanding the sections on fascism, which caused no scandal at all, because Le Corbusier's fascism was rendered as a passing accident. ${ }^{17}$ In 1983 , Macleod documented in impressive

13 My Translation. Chaslin, Un Corbusier, 89. All translations from this book hereon by Simone Brott.

14 Chaslin, Un Corbusier, 89. In fact, Le Corbusier was first accused of fascism in 1934, by the communist architect André Lurçat in Moscow. Jean-Louis Cohen, Le Corbusier et la mystique de l'URSS: Théories et projets pour Moscou, 1928-1936 (Bruxelles, Liège: Mardaga, 1987), 264-265.

15 Peter Serenyi, 'Le Corbusier, Fourier, and the Monastery of Ema,' The Art Bulletin 49, no. 4 (1967): 282 .

16 Charles S. Maier, 'Between Taylorism and Technocracy: European Ideologies and the Vision of Industrial Productivity in the 1920s,' Journal of contemporary history 5, no. 2 (1970).

17 Robert Fishman, Urban Utopias in the Twentieth Century: Ebenezer Howard, Frank Lloyd Wright, and Le Corbusier (New York: Basic Books, 1977). 
detail how in the 1920s Le Corbusier subscribed to American models of industrial rationalization ${ }^{18}$ and believed in Taylorism and the ideology of rationalisation - their power to dissolve class dissonance because of 'the spirit of collaboration' among all classes invested in production. In 1984, Anthony Vidler would align Le Corbusier with Fourier in 'Asylums of Libertinage.' ${ }^{19} \mathrm{~A}$ year later, Macleod's dazzling manuscript Urbanism and Utopia chronicled the architect's leftist activities and affiliations, even while it included Le Corbusier's swerve to the right-indicated in subtitle 'from Regional Syndicalism to Vichy' ${ }^{20}$ The importance of Le Corbusier's early technocratic industrial ideas remains undisputed. Yet the question is why their lineage has been historically ascribed to the political left, to the socialist utopianism for which Le Corbusier is famous, despite the importance of technocracy to French fascism and Le Corbusier's alignment with the first French fascist group Le Faisceau as the context for technocratic ideas in the young architect. ${ }^{21}$ Le Faisceau was partly Saint-Simonian. It intended to build the 'Republic of the producers'. Jarcy challenges the idea that technocracy and Taylorism were the antithesis of fascism. He mentions that Le Corbusier wrote two articles and gave lectures for the Redressement français, a technocratic and Taylorist movement that at that time was considered fascist by both the communists and the fascists. ${ }^{22}$ Finally, Le Corbusier's utopianism was not historicised within a broader discussion of totalitarian avant-garde utopianism, as were say the Italian Fascist architects or German modernists. The attribution of Le Corbusier's early utopian thought and urban plans to the left is due to the lack of architectural understanding of French fascism, but also to Le Corbusier's left-leaning manifesto on la révolution in his 192os' revue L'Esprit Nouveau (LEN) as well as his first book, Vers une

18 Mary McLeod, “'Architecture or Revolution”: Taylorism, Technocracy, and Social Change,' Artjournal 43, no. 2 (1983).

19 Anthony Vidler, 'Asylums of Libertinage: Sade, Fourier, Ledoux,' Lotus International 44 (1984): 28-40.

20 Mary McLeod, 'Urbanism and Utopia: Le Corbusier from Regional Syndicalism to Vichy' (PhD diss., Princeton University, 1985).

21 Mark Antliff, 'La Cité Française: Georges Valois, Le Corbusier, and Fascist Theories of Urbanism,' in Fascist Visions: Art and Ideology in France and Italy, ed. Matthew Affron and Mark Antliff (Princeton: Princeton University Press, 1997), 134-170; Antliff, Avant-Garde Fascism; Simone Brott, 'The Ghost in the City Industrial Complex: Le Corbusier and the Fascist Theory of Urbanisme,' Journal of Architecture and Urbanism 40, no. 2 (2016): 131142; Simone Brott, 'In the Shadow of the Enlightenment: Le Corbusier and Georges Valois,' Proceedings of the Society of Architectural Historians Australia and New Zealand 30 (2013): 777-789.

22 Jarcy, Le Corbusier, un fascisme français, 63, 72-75. 
architecture, which in its promise of social revolution captured his vision for architecture and urbanism. ${ }^{23}$ I suggest it was Le Corbusier's construction of his political philosophy, and the attendant disciplinary myth surrounding his early writings, that contributed to this dominant view.

In Right historiography, evidence of Le Corbusier's fascism was available in France since the French translation of Fishman's book in $1979^{24}$ and available at the Fondation archives from 1970, in the form of Le Corbusier correspondence which became a key source for Chaslin's book..$^{25}$ Yet, until 2015, the largely English writings on fascism did not take the form of condemnation of the French books; and they were somewhat backgrounded by the earlier dominant view that Le Corbusier was either left or nothing at all. In Fishman's brief and neutral presentation, Le Corbusier is portrayed as having mistakenly followed the syndicalists and then Vichy; and his grim professional failures that attend that mistake predominate the narrative. This account stands as an anathema to fascism - viewed as an order of excessive power-because Le Corbusier is shown to have had none. To Fishman, Le Corbusier's fascist tale is a tale of standing outside the order of power - and on that weak foundation, he loses any strong fascist identification. When I asked the Fondation why they objected to the accusation of Le Corbusier's fascism by Chaslin or Jarcy when those claims had been mentioned by Fishman, the answer I received was that Fishman presented a fair and balanced version of the truth contrary to the French authors. Perelman argues: 'in no passage of his chapter on Le Corbusier, [does] he [Fishman] characterize him precisely. On the contrary, he said: "Although he was neither a fascist nor a collaborator, he put his talents at the disposal of a regime that was both".'26 But Fishman's version contains one irregularity: 'Vichy was the culmination of a twenty year long path,' contradicting his position that fascism was accidental. Fascism was discussed in Macleod's dissertation Urbanism and Utopia, while it neither forms a significant portion of what is the longest and most famous study of Le Corbusier's political thought, nor does it name Le Corbusier as a fascist. Le Corbusier's affiliation with

23 Simone Brott, 'Architecture et Révolution: Le Corbusier and the Fascist Revolution,' Thresholds 41 (2013): 146-157.

24 Robert M. Fishman, L'utopie urbaine au XXe Siècle: Ebenezer Howard, Frank Lloyd Wright, Le Corbusier (Bruxelles, Liège: Mardaga, 1979).

25 Claude Massu, 'Le Corbusier reconsidéré: À propos des livres de François Chaslin, Xavier de Jarcy, Marc Perelman,' la vie des idées.fr, 24 October 2015, http://www.laviedesidees .fr/Le-Corbusier-reconsidere.html, accessed 31 October 2017. 'These facts are historically proven and known to all scholars and historians who have studied and continue to study the life and work of Le Corbusier,' my translation. 
George Valois and Le Faisceau, the first fascist group in France in 1927, was first detailed in a completely original chapter by art historian Mark Antliff in Fascist Visions (1997) and later in Avant Garde Fascism (2007) among essays on Art not architecture; and, in later essays by myself. ${ }^{27}$ No one objected to Antliff's chapters - because these were simply not known to the insular architectural discipline, and Antliff's audience was art history, that has a well-established relationship with fascist modernist history. In 2003, Simon Richards devoted two chapters to the topic, 'Syndicalism' and 'Vichy'; but, damning as they were, they were camouflaged within the book's overarching theme Le Corbusier and the Concept of Self that never reverts to total condemnation of the architect. ${ }^{28}$ In 2008, Nicholas Fox Weber's biography of Le Corbusier thoroughly sets out the architect's relationship with Vichy and its pre-cursors, but again makes no judgement on these matters (though he makes it clear that others, notably Pierre Jeanneret, did make judgements). The story of Le Corbusier's fascism presented by three new witnesses in 2015 provides a new level of detail and comprehensiveness (Chaslin and Jarcy), and accusation (Jarcy and Perelman), unseen before. ${ }^{29}$ These are the first books on the architect with fascism as their target.

\section{François Chaslin}

Chaslin communicated that his book was grossly misunderstood, and that he was personally aggrieved by the media exposure, having been subjected to attacks following publication of his book, and what he sees as his unintentional role in the scandal. ${ }^{30} \mathrm{He}$ wrote to me that 'this is a personal work that was

27 Antliff, 'La Cité Française'; Antliff, Avant-Garde Fascism; Brott, 'The Ghost in the City Industrial Complex'; Brott, 'In the Shadow of the Enlightenment.'

28 Simon Richards, Le Corbusier and the Concept of Self (New Haven: Yale University Press, 2003).

29 See footnote 4.

30 Email from François Chaslin to Simone Brott, 2015. He writes 'This campaign entitled "The Fascist Corbusier" was inflated to an incredible, lamentable extent: there are now about 350 articles about it, in 35 different countries. The three books that have appeared by chance are very different in their approach, their ambition and genre. By a sort of media inflammation, an epidemic, their publication has created a globalized problem, a scandalous atmosphere, a campaign that I for my part regretted, and that has served against the appreciation of my own work.' Henry Samuel, 'Le Corbusier was "Militant Fascist", Two New Books on French Architect Claim,' The Telegraph, 16 April 2015, http://www .telegraph.co.uk/news/worldnews/europe/france/11543431/Le-Corbusier-was-militant -fascist-two-new-books-on-French-architect-claim.html, accessed 31 October 2017. 
awarded a literary award under the category biography and [was] never intended as an accusation Le Corbusier was a fascist'-despite his book containing the most substantial evidence of all three. In France, he said 'people have been turning their backs on me since the release of my book as if I had betrayed the cause', and according to the Fondation, Chaslin has mysteriously announced his book is a work of fiction. ${ }^{31}$ Lacking citations but using the purest form of testimony the book examines extensive correspondence, periodicals and texts published by the Fondation pertaining to the question of the architect's fascism both before, during, and after the war. ${ }^{32}$ Chaslin's style is personal, anguished, often a stream of consciousness; nonetheless, he presents astonishing evidence.

It was the eugenicist doctor Pierre Winter who first introduced Le Corbusier to the first fascist party in France, Le Faisceau in 1927. Born out of the split within the Action Française party, Le Faisceau was founded by the journalist George Valois who would publish Le Corbusier's Plan Voisin in his fascist revue Le Nouveau Siècle (1925); and Jacques Arthuys co-founder and vice president of the league, and chief political editor at Le Nouveau Siècle. ${ }^{33}$ Le Faisceau considered Le Corbusier's urban plans the very model for the new fascist order, ${ }^{34}$ and Winter described Le Corbusier as one of les animateurs in Le Nouveau Siècle, meaning 'the organizers' of the Party.

From the early 1930s Le Corbusier did not merely contribute essays to the fascist revues Plans (1931-1933) and Prélude (1931-1936) (35 $^{35}$ but founded Plans in 1931 with the fascists François de Pierrefeu, a polytechnique engineer and urban planner who took part with Le Corbusier in the Vichy regime; Hubert

31 My Translation. Michel Guerrin, 'Le Corbusier, l'architecte de la Cité radieuse, était-il fasciste?' Le Monde, 3/4 Mai 2015, 3-4.

32 Massu, 'Le Corbusier reconsidéré.'

33 Chaslin, Un Corbusier, 97.

34 Ibid., 10o. In 1930 another Faisceau member, Philippe Lamour, considered the father of urban planning in France, gifted Le Corbusier a book dedicated to the architect. Like Valois 'Lamour argued for an urban revolution. He described Le Corbusier's Urbanisme as "the most important book published since the war", advocating a city of freeways and cruciform skyscrapers directly inspired by the Plan Voisin.'

35 Marie-France James, Ésotérisme et christianisme autour de René Guénon (Paris: Lanore, 2008), 210. Chaslin: 'The journal Prélude, which Le Corbusier, in the foreword to [his 1941 book] Sur les quatre routes, claims lasted until 1939 and in meetings of which he will participate in August 1940, yet, although the last publication, the sixteenth, was published on 7 August 1936, it succeeded Plans. It is an interventionist journal (it reads today as technocratic and authoritarian in spirit) to which collaborated big names, a publication whose first issue was released in January 1931 and according to Le Corbusier wrongly declared itself the successor to L'Esprit Nouveau.' Chaslin, Un Corbusier, 119. Note, the year ranges for these journals comes from Chaslin Chapter 6. 
Lagardelle an apostle of French syndicalism (proto-fascism) and Minister of Labour of the Vichy regime; Philippe Lamour, also Le Corbusier's lawyer, a journalist and later urban planner who contributed to the French translation of Hitler's book Mein Kampf; and Winter, another fascist devotee of urban planning who post Le Faisceau founded the Revolutionary Fascist Party. ${ }^{36}$ After the collapse of Plans in 1932 Le Corbusier founded and co-edited its successor Prélude with Winter, Pierrefeu, Lagardelle and chief editor Lamour. ${ }^{37}$ This information was in part provided by Lewis Mumford in 2000 as Chaslin mentions. ${ }^{38}$ Chaslin writes that Le Corbusier was 'necessary to the formation of this ideological groupuscule'; $; 9$ and he claims that Le Corbusier conceived of the three journals as a single project. ${ }^{40}$ When $L^{\prime}$ Esprit Nouveau was under financial strain, Le Corbusier proposed to his co-editors that Plans absorb L'Esprit Nouveau despite a hiatus of seven years. ${ }^{41}$ The priest and editors' friend Benjamin Bordachar wrote that the third revue was not merely a journal but a fascist 'group [that] would ... assume the evocative name of Prélude, and of which one of its heads was le Corbusier.' Chaslin writes 'It [was] a project of a "total reworking", of a kind of totalitarianism.'42

36 Chaslin, Un Corbusier, Chapter 5. The first issue of the magazine Plans, of which he is one of the four members of the drafting Committee, was published in January 1931, structured in three parts. Eric Paul Mumford, The CIAM Discourse on Urbanism, 1928-196o (Cambridge, Mass.: мiт Press, 200o), 296.

Chaslin, Un Corbusier, 119. Also note Macleod claims that Prélude was readily available to scholars at the Fondation contrary to claims by some of the French authors.

38 Mumford, The cIAm Discourse on Urbanism.

39 Chaslin, Un Corbusier, 121. 'In 1930, Lamour assigned the five thematics of Plans to each editor: politics and sociology to himself, applied economics Pierrefeu, town planning and architecture Le Corbusier, health and sports Winter, and art and literature, the architect Jeanne Walter, a French architect who worked on public housing and hospital architecture.'

$40 \quad$ Ibid., 119. Le Corbusier, Sur les quatre routes (Paris: Gallimard, 1941). The date range for L'Esprit Nouveau comes from 'La discorde entre Ozenfant et Jeanneret (1924-25)' cited in Wikipédia, https://fr.wikipedia.org/w/index.php?title=L\%27Esprit_nouveau_ (revue)\&oldid=142028687, accessed 31 October 2017. Chaslin notes Le Corbusier wrongly declared Prélude the successor to L'Esprit Nouveau.

41 Chaslin, Un Corbusier. 'It is odd that LEN in hiatus for seven years should be confused with the endangered Plans or Prélude in gestation ... A letter from Le Corbusier to Philippe Lamour, dated June 26, 1931, about the liquidation of LEN . . proposed a merger with Plans and a "vitalization of reciprocal efforts". Perhaps the architect hoped to keep in one form or another, the existence of its magazine, although Plans appeared already for six months. This shows anyhow the nesting of these successive publications, sometimes confused the timeline.'

Ibid., 203. 
He adds that the smaller triangle, consisting of Le Corbusier, Pierrefeu and Winter, was so intimate that the three were living together in one of Le Corbusier's apartment buildings in 1934 and would continue to work together during the war. ${ }^{43}$ Pierrefeu worked with Le Corbusier and playwright Jean Giraudoux on a government study commission on housing. ${ }^{44}$ Using the results of this study, in 1942 Pierrefeu wrote a book with Le Corbusier, La maison des hommes, at the end of which Pierrefeu wrote that 'he and Le Corbusier would be three if the most authoritative signature, that of Dr. Pierre Winter ... [was included]. Winter would go to Vichy in March 1942, to become a Member of the cabinet of the Minister of labour of Pierre Laval, with their friend Lagardelle. They all gathered in Vichy.' ${ }^{15}$ Chaslin cites Le Corbusier in a flashback to 1927: 'Arthuys, "one of the two leaders of the fascist party," has quite simply made the proposal to appoint me Minister of town planning and housing. ${ }^{36}$ Quoting Fishman, Chaslin notes that in 1941 Le Corbusier, Pierrefeu and the modern architect André Boll were commissioned by the Vichy government to produce a study toward developing a national construction policy. ${ }^{47}$ In 1942 'Pierrefeu and Le Corbusier ask Bordachar to write to the Marshall (Petain), who suggests that town planning work may be reserved for them for the reconstruction .... Le Corbusier ... rejoices. Two months later they hear: "the Minister considers neither close nor far nor any form of collaboration with Le Corbusier, François

43 Ibid., 123. In 1932, Pierrefeu produced a book on Le Corbusier and Pierre Jeanneret.

44 Chaslin cites Mumford: “. . . architect providing drawings and Pierrefeu writing texts ... under the dictation of his friend." Mumford, The CIAM Discourse on Urbanism. It was a bizarre manifesto on occultism that 'criminalised rationalism' and the secular sciences along the lines of syndicalist anti-capitalist ideology.

45 François de Pierrefeu and Le Corbusier, La maison des hommes (Paris: Plon, 1942). Chaslin, Un Corbusier, 114. Original quote: Qu'en pensent ses amis Pierrefeu et Winter, intimes au point qu'ils s'étaient tous les deux entre-temps, au printemps 1934, installés avec lui dans l'immeuble qu'il venait de construire 24, rue Nungesser-et-Coli? À sa mère, le 29 avril : "Pierrefeu est installé au-dessous de moi. Ravi. Winter va entrer au quatrième" (et son dentiste Blumenstein s'installe au cinquième). Leur proximité est telle que, lorsque s'achève La Maison des hommes, Pierrefeu explique en introduction qu'ils seraient trois si la signature la plus autorisée, celle du docteur Pierre Winter, "l'humaniste de notre équipe, de cette vieille équipe formée après l'autre guerre autour de L'Esprit nouveau, et qui rédigea par la suite la revue Plans et le périodique Prélude", n'était en cet été 1941 à Paris et eux deux à Vichy. Mais cela ne durera pas et Winter sera bientôt, en mars 1942, membre à Vichy du cabinet du ministre du Travail de Pierre Laval, leur ami Lagardelle. Tous réunis à Vichy. Eh bien, dans ce milieu des années trente, il semble qu'ils étaient.'

$46 \quad$ Chaslin, Un Corbusier, 98.

47 Ibid., 186. Fishman, L'utopie urbaine au XXe siècle, 184. Yet in July the government cancelled the project. 
de Pierrefeu and André Boll." All three were effectively fired from their office and hotel rooms. 48 It is difficult to maintain Le Corbusier was never a fascist certainly under Vichy he was, and openly. This was undisputed until 2015. Also consider that Le Corbusier fell out with his cousin Pierre Jeanneret-Gris in the 1940 s because Pierre joined La Résistance and Le Corbusier did not. Le Corbusier made a choice. Not all the French avant-garde adhered to fascism.

As per Weber's biography, Chaslin writes, in 1943, the eugenicist, surgeon Alexis Carrel appointed Le Corbusier Technical Advisor of the Department of Bio-Sociology within Carrel's research Institute, the Foundation for the Study of Human Problems, Carrel founded in 1941 at Vichy, which implemented his eugenic policies. ${ }^{49}$ 'In 1936, Carrel congratulated the National-Socialist Government for having "taken energetic measures against the increase of minorities, the mentally ill, and criminals".50 During Vichy, Le Corbusier wrote to his publisher that Carrel had authorized him to dedicate his book Sur les quatre routes [On the Four Routes] (1941) to the doctor who was also invited to write its preface and would further endorse it. ${ }^{51}$ Sur les quatre routes has three pages of dedications to fascists groups including L'Action Française; to the Legion of Xavier Vallat, Commissioner-general for Jewish Questions; to Petain; and to Pierre Caziot, Secretary and signatory to the Jewish laws. In it Le Corbusier writes: 'In this severe upheaval, a glow of good: Hitler seeks healthy materials and wishes by this return to traditions to rediscover a robust health that can discover in every race, whatever it [truly] is.' Elsewhere, Le Corbusier wrote, 'the task of reconstruction by the Marshal Petain ... is to firstly build a new moral order, beautify the country by architecture ... conducive to the regeneration of the race.52 In 1944 Maximilien Gauthier published the first systematic

48 Chaslin, Un Corbusier, 206.

49 Ibid., 217. See also Robert M. Sade, 'Transplantation at 100 Years: Alexis Carrel, Pioneer Surgeon,' The Annals of thoracic surgery 80, no. 6 (2005): 2415-2418. Andrés Horacio Reggiani, God's Eugenicist: Alexis Carrel and the Sociobiology of Decline, vol. 6 (New York: Berghahn Books, 2007). William H Schneider, Quality and Quantity: The Quest for Biological Regeneration in Twentieth-Century France (Cambridge: Cambridge University Press, 2002); Andrés Horacio Reggiani, 'Alexis Carrel the Unknown: Eugenics and Population Research under Vichy,' French historical studies 25, no. 2 (2002).

$5^{0}$ Chaslin, Un Corbusier, 218. He also wrote 'Eugenics demands the sacrifice of many individuals.'

$5^{1} \quad$ Ibid., 184. In 1941 Gaston Gallimard sent Le Corbusier (Carlton hotel, Vichy) the revised manuscript of Sur les quatre routes via Winter. In his note he stated that his notes were simple suggestions and do not require major revisions with the exception of the passages relating to architecture in totalitarian countries that were carefully censored. Ibid., 185. My translation is a precis of the original.

Ibid., 187 . 
biography: Le Corbusier or Architecture in the Service of Man which argued that Le Corbusier had more than simply housing, streets and cities in his sights, his target was man himself, his biology, his race, his life. ${ }^{53}$

One objection to this material is that eugenics was also popular among some communists. As communism desired to build a new man, some communists were eugenists; alternatively, Lyssenko, who was the 'official' biologist of the Stalinist regime, condemned eugenism. But importantly the context for Le Corbusier's eugenic ideas was Carrell and the fascist Vichy machine; and, eugenics at the time Le Corbusier adopted it was a major aspect of fascist ideology in Europe. An author from the Corbusian side who wishes to remain anonymous writes that

In a joint effort of our two journalists, Corbu is abundantly associated with Alexis Carrel although the exchanges between the two men are reduced to a few couriers, and without Le Corbusier ever expressing any adherence to the racial theories of Carrel. The conference he gave to the Carrel Foundation in February 1943 resumed his speech on the radiant farms and villages but also his work undertaken for the $\mathrm{CIAM}^{54}$ [conference of] Athens or that of Paris of 1937 on Housing and Leisure, [were] fully inspired by the Popular Front. Nothing infamous or suspicious appeared in this conference where the evocation of the conditions of nature, of solar rhythm and the house dominates ... Apart from the fact that Carrel belongs to the (very) many characters left or right ... they agree on this need to clean up the cities. When Le Corbusier states that it is necessary to put an end to the slums, those of Algiers or the unhealthy island No. 6 in Paris, he does not do so in the name of any eugenic or racial theory or ... sterile rejection [of] the suburbs, but in the name of hygiene, which would make health a condition of life or nature essential to the development of man. ${ }^{55}$

This is an attempt to separate Le Corbusier from Carrell by way of Le Corbusier's work on health. However, what both Chaslin's and Perelman's books demonstrate is that biology, health, and hygiene were key to Le Corbusier's political thought, terms that were already linked to Le Corbusier's racism (that was established prior to the books), and not merely cleanliness. In my visit to

\footnotetext{
53 Ibid., 219.

54 Congrès Internationaux d'Architecture Moderne.

55 My Translation. Anonymous, 'Notes de Lecture: Le Corbusier et Le Fantasme Francais' (Paris 2016).
} 
the Fondation in 2013 I identified that Le Corbusier's project on health was inspired by the fascist doctor Winter, and that this was a life-long collaboration. For Winter, 'Le Corps Nouveau' was the key ideological instrument of the fascist city, as he wrote in one of three essays Le Corbusier printed in L'Esprit Nouveaux. ${ }^{56}$ Le Corbusier would champion Winter's book manuscript Biology, Medicine, and Urbanism for which he wrote a preface. I suggest Winter was the lynchpin of what Chaslin called the fascist 'groupuscule' - Pierrefeu, Le Corbusier, Lamour, and Lagardelle - and he was also the narrative link that connected Le Corbusier's early participation in Le Faisceau with his term at Vichy in the 1940 .

As Richards identified, 'cleanliness' and 'hygiene' appear in far-right political references by Le Corbusier, specifically his belief in the 1930s that parliamentary democracy had to be 'cleansed', while he was involved with the far-right Action Française, and later the Croix de Feu, and Jeunesses Patriotes, the latter who instigated the antisemitic riots against the Jewish financier Stavisky, using the same discourse of hygiene and cleansing. ${ }^{57}$ The argument 'Hygiénisme et non eugénisme' is misleading because the former contains racial significance in Le Corbusier, such as his reference to the antisemitic Stavisky scandal in a photograph of the bloody riots that he admired and reprinted in $L a$ ville radieuse (1933), and captioned 'February $6^{\text {th }}$, 1934, in Paris: awakening of cleanliness. 58 But, beyond Chaslin's account, there is no further information at the Fondation on the work Le Corbusier conducted for Carrel—so we cannot detail Le Corbusier's eugenics project if there was one. But there is abundant evidence of Le Corbusier's racism and antisemitism that would tie him to Carrell's brand of eugenics, rather than the communist variety or interest in beautifying the modern city.

Le Corbusier held racist views and was a passionate antisemite. He wrote a paranoid letter to Auguste Perret in 1914 about the Jewish race, and another to William Ritter, in 1917, another Swiss antisemite, in which Le Corbusier refers to his own 'hallowed antisemitism'. Chaslin describes Le Corbusier's racist caricature of Léonce Rosenberg an art historian, art collector, publisher and one of the most influential French dealers of modern art in the twentieth century. The real reason Le Corbusier hated Rosenberg was because Rosenberg refused to lend him paintings by Braque and Picasso to decorate the Esprit

\footnotetext{
56 Chaslin, Un Corbusier, 99. Pierre Winter, L'Esprit Nouveaux, février 1922.

57 Brian Jenkins and Chris Millington, France and Fascism: February 1934 and the Dynamics of Political Crisis (Abingdon, New York: Routledge, 2015), 59, 164.

$5^{8}$ Richards, Le Corbusier and the Concept of Self, 43-44.
} 
Nouveau Pavilion. ${ }^{59}$ In revenge Le Corbusier published an antisemitic cartoon of Rosenberg in his book. In an unpublished letter by Le Corbusier in 1938: 'Since Jews are hunted in the course of wandering, we should give them an area to relocate [he offers French Guiana] because they are accustomed to the ghetto.' He adds, 'they [the Jews] should consult me about urban planning of their new settlement'.60

Macleod objects to naming Le Corbusier an antisemite, drawing on an account from 'Luc Aujame the son of Roger and Edith Aujame, who both worked for Le Corbusier from 1942 - that Le Corbusier helped Roger stay with a friend of his in the 16th Arrondissement to escape the Nazis who were pursuing him. Edith was Jewish. ${ }^{61}$ Yet, just because Le Corbusier was loyal to Jewish friends does not mean he was not an antisemite. E.g. under Nazi race laws, Ernst Hess, an officer in Hitler's unit in World War I, was found to be Jewish, and a candidate for liquidation. 'He was spared the Nazi death camps by personal intervention from "the Fuhrer".'62 Chaslin writes about Cohen's attempt to acquit Le Corbusier of antisemitism in response to the 'campaign of vilification in Switzerland a few years ago.' ${ }^{63}$ The journalist Michel Guerrin also refers to the incident: 'In 2010, the historian Pierre Frey calls Corbu ... [a] violent antisemite who without a struggle built for Hitler, provoking thus the withdrawal of an advertising campaign of the UBs bank that used the face [of] Le Corbusier.'64 Cohen's response is that Le Corbusier employed a number of Jewish Zionists to which Chaslin writes: 'This obviously does not prove much. ${ }^{65}$ The rebuttal is the same as the one to Le Corbusier had Jewish friends.

59 Chaslin, Un Corbusier, 146.

60 Ibid., 147. Jews migrated to Guiana in 1500 fleeing the Inquisition in Spain and Portugal.

61 Email from Mary Macleod to Simone Brott, 1 January 2015.

62 Heinrich Himmler, 'Letter Granting Hess "Relief and Protection as Per the Führer's Wishes"' (27 August 1940). Cited in David Lawlor, 'Hitler's Favourite Jew...., historywithatwist weblog, 6 July 2012, https://historywithatwist.wordpress.com/2012/07/06/recallin-hitlersfavourite-jew/, accessed October 31, 2017.

63 Chaslin, Un Corbusier.

64 Guerrin, 'Le Corbusier, l'architecte de la Cité radieuse,' 4.

65 Cohen, who has family connections with the jewish millieu in La Chaux-de-Fonds acknowledged the antisemitic statements by Le Corbusier but adds 'Le Corbusier's friendship with certain Jewish clients, the sculptor Chaim Jacob; and, the presence in his office of architects who will emigrate to Palestine, like the Belarusian Shlomo Bernstein or Sam Barkai, and his apparent sympathy for the Zionist project. Cohen spoke of an unpublished text, written in December 1938 for one of his most active representatives, Wolfgang von Weisl: "Indeed, it is the whole of Europe and not only the six million Jews of the country beyond the Rhine that hangs the threat of annihilation. The Jews were the first victims, but they cannot remain the last or only prey for the unleashing of the racial passions"'. 
Cohen writes that Le Corbusier's antisemitism is of a different order than that of say 'Céline or Le Corbusier's master, Auguste Perret, president of the order of architects under Vichy which excludes Jewish members ... [and] that others do not make these nuances. ${ }^{66}$ But this argument about degrees of antisemitism does not acquit Le Corbusier, the varying degrees of hatred does not place a person outside of hatred. The anonymous author of 'Le Corbusier et le fantasme français' makes a similar objection: 'there is nothing that can testify to militant antisemitism as was the case of Brasillach, Rebatet, Drieu La Rochelle, Céline ... What would be his acceptance as a member of the Jewish Circle of La Chaux-de-Fonds on November 30, 1914, especially as he is accepted ... with more than two thirds of the votes, as required by the regulations. This closed circle would not have accepted an antisemite within it.' ${ }^{67}$ The question is why then did Le Corbusier write extreme antisemitic statements after having been welcomed by the Jewish circle as a member? Jarcy's response is:

At that time, Le Corbusier had already been publicly accused of antisemitism, because he had designed the plan of a new district in La Chaux de Fonds, in which he placed the Jews in a separate zone ${ }^{68} \ldots$ It is true he was not a militant [antisemite]. But he was surrounded by people Lamour, Lagardelle, d'Eaubonne - who spread antisemitic allusions ... and he praised Giraudoux's Pleins Pouvoirs, a racist, antisemitic, antimasonic and eugenist book. ${ }^{69}$

Chaslin presents the evidence of Le Faisceau, Vichy, eugenics, and antisemitism with an unprecedented level of detail and vigour by inserting the reader within the fascist millieu surrounding the architect, and for this he should be commended. But unlike the other authors he does not condemn Le Corbusier's collaboration or antisemitism sometimes even excusing it: 'Maybe Corbu was a banal antisemite, anti-Semitic without particular hatred and also pragmatic, considering that any problem, the "Jewish question" in particular, could find a solution by town planning. ${ }^{.70}$ In Chapter 11 he provides what is a sympathetic

66 Cohen quoted in Guerrin, 'Le Corbusier, l'architecte de la Cité radieuse,' 4.

67 Anonymous, 'Notes de lecture: Le Corbusier et le fantasme français,' 2.

68 Marie-Jeanne Dumont, ed., Le Corbusier, William Ritter: correspondance croisée 1910-1955, lettres à ses maîtres III (Paris: Linteau, 2014), 332-333. In a letter to Ritter, on 29 November 1914, Le Corbusier says: 'Mon histoire d'antis ... me tombe dessus et m’écœure,' 332.

69 Email from Xavier de Jarcy to Simone Brott, 13 February 2017.

70 A faintly antisemitic explanation. 'It is anti-Semitic because it is normal at the time and even "intellectual", in the workplace, in its various settings and in the entourage of $\mathrm{Au}$ guste Perret in Paris.' Just because antisemitism and murdering Jews was 'normal' under 
reading told from the point of view of the fascists about Le Corbusier's 'hard times at Vichy,' which is outrageous given that the architect's memoirs were written while France's Jews were being systematically persecuted, rounded-up and deported to Drancy, on route to death at Auschwitz. Chaslin's history does not mention the Commissariat Général aux Questions juives [CommissariatGeneral for Jewish Affairs], created by the Vichy State in March 1941, that appropriated Jewish residences, or that even after the war the French refused the Jewish survivors their homes and continued to organize anti-Jewish propaganda. This chapter treats Jewish history from the perspective of the persecutors, the lack of hygiene in Marseilles, the need for architectural reconstruction of Marseilles after the evacuation of the Jews, and Le Corbusier's desperate unsuccessful bid to get this work. ${ }^{71}$ In short, the humiliation of the French fascists does not make compelling reading. Chaslin emerges as ambivalent about Le Corbusier's fascism, after having demonstrated vast evidence, denying it: 'Authoritarian or even totalitarian architectural inclinations in Le Corbusier are a kind of folklore. ${ }^{72}$ Chapter 12 is filled with statements to the effect that calling Le Corbusier a 'Nazi' and the Swiss campaign against him is 'laughable'. He denounces multiple accusers of Le Corbusier's fascism. Chaslin is perhaps attempting to differentiate between Le Corbusier and the Nazis or militant collaborationists like Doriot. He is correct in this regard as Le Corbusier didn't deliver Jews to the Gestapo and he didn't publically expressed his hatred. But he was an accomplice of collaborationists and he clearly approved Pétain's criminal policy against the Jews. Jarcy writes: 'One must always remember that the Vichy regime was not only authoritarian, but also an ally of Hitler in his

the Third Reich does not legitimate it, a point so obvious that it scarcely needs to be mentioned. Using Hitler's exact phraseology Chaslin writes: “The "Jewish question" and antisemitism are European.' The Jewish question of course meaning how to rid Europe of its population of Jewry which led to Hitler's 'Final Solution', Nazi-speak for the extermination of six million Jews in Europe. Next, I want to correct an inaccuracy. Chaslin writes about the antisemitism of one of Le Corbusier's colleague's the Swiss architect Alexander von Senger who 'in 1931 ... along with other Nazi architects such as Eugen Honig, Konrad Nonn, German Bestelmeyer, and especially Paul Schultze-Naumburg ... [was] deputized in the National Socialist fight against modern architecture, in a para-governmental propaganda unit called the Kampfbund deutscher Architekten und Ingenieure (KDAI).' Chaslin writes that Senger used the term Mammonisme, a pejorative code word for Judaism: 'Of Greek origin, Mammon came to us by the Hebrew or Aramaic, meaning money, wealth, possibly improperly acquired.' In fact, the word mammonisme does not appear in the old testament but in the new testament and the Koran. It is not Jewish but a projection onto judaism, which is the basic instrument of antisemitic ideology. Chaslin, Un Corbusier.

71 Ibid., Chapter 14 on the jews in Marseilles.

72 Ibid., 260. 
criminal fight against the Jews, the communists, the trade-union members, the freemasons. And Le Corbusier couldn't ignore this. ${ }^{73}$ So, to the Telegraph, this book does not accuse Le Corbusier of being a fascist, but confirms it. Despite this conflict, Chaslin's book is an immense work that contributes to historiography.

\section{Marc Perelman}

Perelman's book is a systematic denunciation of Le Corbusier studies and Le Corbusier's oeuvre, from the Five Points of Architecture and Le Modulor to the Unité d'habitation buildings and urban planning projects. If Chaslin is guilty of not punishing Le Corbusier for the crime his book makes evident, Perelman's book provides that punishment, a relentless indictment done via Marxist and psychoanalytic critique that at no point admits any of the merits of Le Corbusier's oeuvre or his positive achievements: his plastic work, his formal invention, and his writings and philosophical questions.

First, Le Corbusier studies 'resemble a large religious sect'; 74 and it 'relies mostly on abstract architectural data by Le Corbusier without critical examination. ${ }^{75}$ 'The reign ... of an empirical sociology, quantitativiste and ... positivist, which analyses only the brute facts and the definitive a priori givens' results in an impoverishment of theory he calls 'the worst form of pragmatic history'. ${ }^{76}$ Perelman is referring to the familiar disciplinary methodology that reproduces archival materials in forensic detail describing e.g. the gloss and thickness of the paper, the type of font. 'The accumulation of objects ... (books, paintings, sculptures, tapestries) absorb, petrify and block reflection' because they 'reify' (commodify) those objects i.e. turn them into visual fetishes, in what is a classic Marxist argument. ${ }^{77}$

Next, Perelman attributes to Corbusian historiography the problem where historians excuse the crimes of an historical figure by casting them as 'servile protagonists' 'who are merely the children of a time and could be excused for their errors.' This is a bad argument says Perelman because 'all humans are

73 Email from Xavier de Jarcy to Simone Brott, 13 February 2017.

74 My Translation. Perelman, Le Corbusier, 7. 'With its guru, his followers . . . rituals ... initiations ... the commemoration of symbolic dates, visits to places of pilgrimage ... incantations to the lost figure, and mythifications ("the greatest architect of all time").' All translations from this book hereon by Simone Brott.

75 Ibid.

76 Ibid., 29 .

77 Ibid., 30. 
"children of a time" and if this becomes the supreme reason, then we should never attack anyone, because they cannot have acted otherwise. ${ }^{78}$ We can look to avant-gardists who joined the Resistance: Pierre Jeanneret (Le Corbusier's cousin), Paul Eluard (poet and one of the founders of surrealism), Lucien Hervé (Le Corbusier's photographer), or Tristan Tzara.

Further, 'There is a huge blind spot in French historiography about Le Corbusier ... [from the] 1920-1940s and World War II. There are also large holes in the archives of the Fondation, "Where are Le Corbusier's diaries from 1936 to 1945 ?"79 He summons Jacques Lucan of the Pompidou Centre's Le Corbusier Encyclopedia for glossing over Le Corbusier's time at Vichy, ${ }^{80}$ and Cohen for 'relativising Le Corbusier's extreme political acquaintances.'81 Perelman argues the alleged historical distortion of Le Corbusier was of a monumental national scale, arguing that to preserve its intellectual heroes, after the war, France 'passed the sponge over Vichy' in what was called France's l'epuration [the purging of Nazi sympathisers]. This disconnected intellectuals like Le Corbusier from Vichy.

The methodology Perelman will now use to re-brand Le Corbusier's oeuvre as 'totalitarian' is pure French theory of the post- 68 tradition. To justify his bold premise Perelman argues that Le Corbusier's politics cannot and should not be separated from his work, that his writings and buildings all converge on his fascist political project. ${ }^{82}$ Perelman sees in Le Corbusier's grand scheme for the 'measurement of life itself' a sinister order that is a form of oppression and control by a supreme nature without any intermediary like free will or choice. ${ }^{83}$ He derides Le Corbusier's 'oss/bone' architecture 'the identification with the skeleton ... an assemblage of bones organized by nature ... cleaned of all flesh. ${ }^{84}$ For Perelman this is not a metaphor of the body but of death - life as such takes place under the authority of this figure of death he calls 'a large ossuary.' ${ }^{85}$ As such, it 'rests on a pathological foundation' namely a Freudian regression, making it not modern at all. ${ }^{86}$

$7^{2}$ Ibid., $25^{-26 .}$

79 Ibid., 56. This remains controversial and unconfirmed, as to the incompleteness of the archive, denied by the Fondation.

8 o Ibid., $5^{8-59}$.

81 Ibid., 62.

82 Ibid., $56-57$.

83 Ibid., 77-78. Le Corbusier, Vers une architecture (Paris: Editions G. Crès et Cie, 1923), 56.

84 Perelman, Le Corbusier, 88-89. Le Corbusier, Sur les quatre routes, 63 . Note, the word for frame in French is cadre which also means body or chassis in French. The French word oss means a skeleton or framework. So this is as much a problem in the French as English.

85 Perelman, Le Corbusier, 89-90.

86 Ibid., 111 . 
Next, he theorizes the false notion of freedom in Le Corbusier's concept the 'free plan':87

The interior space ... [is] a free space for a global vision. [It] admits of no screen or continuous surface that would arrest the gaze. The empty space is a transparent volume where the spectator-inhabitant visualizes the void up to the openings; the view extends past the window in length opened on the landscape, from the inside to the outside ... The inhabitant is now in a relation of alienation with his habitat... in the sense that nothing is close ... An ... ontological substitution has ... occurred between the whole of the body and a fragment of it, ... the eye ${ }^{88} \ldots$ This alienation, in the first sense of the term, evacuates the body from the interior, in a way that de-inhabits the apartment. ${ }^{89}$

Chapter 6 proceeds with an assault on each of Le Corbusier's Five Points of Architecture, primarily the tyranny of the gaze and totalizing effects of Corbusian visuality..$^{90}$ The eye in Perelman's theory is the architecture itself, selfaware, it not only controls the vision of the inhabitant, what he sees and so on, but liquidates the subject's own consciousness as he becomes a docile servant of the architecture. Perelman's critique is so dazzling in its abstractness and intellectual virtuosity that on the one hand it's froid and on the other hand it explains Le Corbusier's Cinq points better than Le Corbusier ever could have. He cites Beatriz Colomina's work on the gaze, but the undeniable brilliance of his prose transcends any theoretical critique of Le Corbusier in the Anglo-American academy. Perelman's espace froid is compelling reading, but not equivalent to fascism - there being no test for whether an architecture constitutes a general fascism or fascist regime, and the very large difference between naming a city and a building fascist - but neither does Perelman definitively use the word fascist, favoring the term totalitarian. Fascism or fascist are not part of his book title. If we accept Perelman's reading of the gaze, Le Corbusier invented a language so interior, so severed from anything real, that it scarcely relates to any political system let alone fascism which was anti-rationalism. I suggest the abstract system of the gaze finds its model in German philosophy not in French politics. The Corbusian world of hyper-rationalism and cold idealism

87 Ibid., 112-13. Le Corbusier, La ville radieuse: Éléments d'une doctrine d'urbanisme pour l'équipement de la civilisation machiniste: Paris, Genève, Rio de Janeiro (Paris: Éditions Vincent, Fréal et Cie, 1964, reprint of the 1933 edition), 33.

88 Perelman, Le Corbusier, 116.

89 Ibid., 114-115.

90 Le Corbusier, Le Modulor (Paris: Denoël-Gonthier, 1977), 78. Perelman, Le Corbusier, 130. 
might fit more easily within the philosophy of Platonism or Hegel post-Kant, not the hot syndicalisme of Valois or Sorel..$^{91}$ On the other hand, the reading that follows gets closer to its prize.

Perelman writes, that for Le Corbusier, 'society is in its entirety understood as a body under the authority of an assemblage of different machines ... welded to each other.92 The Corbusian city becomes a vast cyborg, with the implication that all humans are evacuated, having become cyborgs plugged into the larger machine. This effectively describes the totalitarian subordination of the individual to the State via a sinister technology and co-option of the body therein.

A few years before his death Le Corbusier wrote 'the city is biology' describing his work in 1922 as a micro-biologist who 'undertook laboratory work', produced a 'diagnosis' and 'thus cleared the fundamental principles of modern urban planning. ${ }^{93}$ Perelman quotes Le Corbusier in 1960: 'We have need for a diagnosis and a line of conduct. In 1922, I tried to enter into the analysis, and undertook laboratory work. Isolating my microbe, I watched how it developed. The biology of my microbe appeared in indisputable clarity. Certainties were acquired and a diagnosis. Then, by an effort of synthesis, I cleared the fundamental principles of modern urban planning.' This shows Le Corbusier held these biological notions right until his death. 'The goal is to create a protoplasma-envelope, an identical cell membrane for each housing repeated to infinity, on the model of the human cell. ${ }^{94}$ This would be merely another banal metaphor but for the attempt to fit humanity into this model. In Urbanisme Le Corbusier castigates 'the man with two legs, a head and a heart - an ant or a bee subservient to the law, fitting into a box, behind a window; [yet who] ... crave[s] total freedom, a total fantasy, in which each would act according to his will ... It is a law of human biology, the square box, the room ... The dwelling [must be] able to hold the inhabitants of cities ... to hold them back. ${ }^{\prime 95}$ Perelman concludes this is a totalitarian definition of housing, insofar as it

91 I previously discussed the philosophical genealogy of Le Corbusier's urban philosophy such as German idealism in Brott, 'The Ghost in the City Industrial Complex.'

92 De Pierrefeu and Le Corbusier, La maison des hommes, 144. Perelman, Le Corbusier, 124.

93 Perelman, Le Corbusier, 132. Le Corbusier, Precisions: Sur un etat present de l'agriculture e et de l'urbanisme (Paris: Freal, 1960), 144.

94 'The initial core of urbanism is a residential cell (a logis) and its insertion in a group forming a housing unit of effective size ... the cell is the primary biological element.' Le Corbusier, Jean Giraudoux and Jeanne de Villeneuve, La Charte d'athènes (Paris: Éditions de Minuit, 1957, reprint of the 1943 edition), 110. Perelman, Le Corbusier, 137. Le Corbusier, La ville radieuse, 143 .

95 Le Corbusier, Urbanisme (Paris: Éditions Vincent, Fréal \& Cie, 1966, reprint of the 1924 edition), 101. 
represents a carceral conception of housing. But is it fascist? Perelman's rendering of Le Corbusier suggests a eugenic model of architecture as a biological instrument of population control. But to make eugenics specifically fascist, it would need racism - Le Corbusier's racial ideas for housing. What Perelman demonstrates is that Le Corbusier was not merely using Carrel for political advantage but passionately believed in the biological 'control' model of the city and social life.

The most compelling evidence in the book is the discussion of sport in Le Corbusier's oeuvre. First, Perelman confirms that Le Corbusier and Winter shared a sports ideology, and formed a joint project that issued directly from Le Faisceau. Perelman cites Winter in a statement that could have been written by Le Corbusier: 'In an article written late 1940 and published in hospital records (No. 11-12, 1942), [Winter] discusses ... the great Vichy tradition and fascist return (the myth of a true origin) to "the great laws that direct the lives of the men on the planet, close to life, natural life" "the ... natural laws of life, the cosmic rhythms which determine our organic balance and to which we must obey".'96 Winter then ascribes to Le Corbusier the task of curing France: 'We speak of one who will take responsibility for the health of France, one who, with the help of town planning, physical culture and sport, will finally find his true effectiveness.' Winter's essay 'Work, physical and sports culture' published in the monthly journal of general education and Pétain sports stadiums (1944), theorizes 'sport as a link between the workers and the bosses. A link which would allow the struggle of classes not to develop'; ${ }^{\prime}$ in other words, using the syndicalist arguments of Le Faisceau.

On Le Corbusier's advice, Winter also developed the idea that the French government (Pétain) must 'build healthy logis everywhere, with their logical extension: the sports facilities, without which they would be inconceivable.' Also 'The ville radieuse is a thick weft of tangible [sports] centres, a dense connective tissue of land and equipment, a chessboard with sports bases.' Sports fields were to be built at the foot of houses combined with Le Corbusier's injunctions for workers and their families to undertake daily 'essential bodily activities' which would connect the workers to their bosses. 'Like a cellular tissue, the urban system is defined by the movement of sports, by bodies mobilized and framed.' 'It is through sport or physical activity that the body is structured to densify the urban fabric.' 'Sport means filling the free areas, gaps between the architectural buildings . . . and to fill the day of urbanized individuals.' 'Planning equates "free" time to

\footnotetext{
96 Perelman, Le Corbusier, 53-54.

97 Ibid.
} 
sports time.' Perelman argues: 'This "sportivisation" of everyday life, is parallel to the "sportivisation" of economic life. The entire social structure is designed as a Sport, a violent ... battle between all men: the weak [versus] . . those who want to win.' He concludes, sport is 'the perfect totalitarian idea of urban society: competition, war, performance, discipline, etc.' Note, Le Corbusier also subscribed to social Darwinism, the idea that the totality of social life is a biological competition or war in which only the strongest survive. Perelman does not use the term fascist, here, but if fascism means a regime that subordinates every act of the individual to the state and to its ideology - then he makes a case with the example of sport that Le Corbusier's city, if ever realized, could be called a fascist city. ${ }^{98}$

In his book, Perelman is not only naming the body and biology as key instruments in his definition of Le Corbusier's fascism, he is using the body as the key instrument of his critique, in the tradition of Foucault, Deleuze and the radical French left. The Fondation dismisses this as 'Foucauldianism' and therefore nothing at all to do with Le Corbusier or fascism. Yet such a neo-Marxist biopolitical critique is entirely appropriate to the question of Le Corbusier's fascism for the very reason that European fascism grew out of the French Marxist tradition from the nineteenth century, and reactionary movements during the French enlightenment, and it reemerges in the post-68 Foucauldian milieu whose target was precisely fascism - not a named regime or political system but a covert psychoanalytic phenomenon exploited by the State. If Perelman's critique of the gaze and of hyper-rationalism in Le Corbusier does not sound like true (political) fascism, the biological conception of architecture as a method of cleansing the city-state, and subordinating the individual to it, does, as does the sports-corporation dystopia that micro-managed the citizen at every level from the social to the cellular. Perelman's critique is Foucauldian, precisely because it is anti-fascist.

98 Some might argue that the 'sportivisation' of everyday life could be considered an attribute of socialism, but sportivisation in Le Corbusier appears in the historical context of La ville radieuse, after Le Corbusier had joined the syndicalist movement, which is also a key source of evidence of Le Corbusier's fascist thought in Chaslin and Perelman and is unrelated to Le Corbusier's earlier socialist ideas. Jarcy comments that 'LC's so-called urban biology, including sport, comes from Winter, and this is why we can call it fascism. LC himself knows nothing about biology, he just repeats what Winter says. And Winter is influenced by Maurice Boigey, a military doctor who in 1917 wrote L'Elevage humain (The Human Breeding), in which he advises using sport to build a new race. Boigey thinks that physical strength can be transmitted through generations. He is a Lamarckian who has read Galton.' Xavier de Jarcy, Email from Xavier de Jarcy to Simone Brott, 13 February 2017. 


\section{Objections to the Books (The Criminal Defence)}

The first objection to these books is that they were part of a mediatized hyperbole - as confirmed by Chaslin's experiences. The urban architect Jacques Sbriglio describes the three books as Lynchage médiatique. ${ }^{99}$ Macleod objects to Chaslin's book on the grounds that it is essentially an argument of 'guilt by association'. Yet from Le Corbusier's founding role in fascist journals, and activities in fascist groups, and especially Bordachar's testimony, the evidence is hard to dismiss. The same anonymous author from the Corbusian front raises an important objection - these works condemn an architect based on his personal biography. This is true for Jarcy, but not Chaslin who does not condemn the master, or Perelman who criticizes the work itself. Here is a classic argument about the illegitimacy of ad hominem criticism, ironically in an age where a person's life has become the object of all interest. He says that until recently biography was kept separate from the architecture. But now, it is 'Tell me who you were, how you lived, and I can reveal the truth about your work ... [Further] The exact nature of the threat that it [Le Corbusier's work] is supposed to embody must be questioned.'100 Le Corbusier's modern thought and praxis is now so internalized in architectural pedagogy, in the contemporary city itself, that this question is reasonable, what threat can Le Corbusier's buildings pose today, almost fifty years after his death? Such an historical revision rather represents a threat to Corbusian historiography, and to the understanding of his urban plans. No matter how great Le Corbusier's intellectual and artistic genius and contribution, because he was not only an architect but also a profound philosopher and prolific author, his political thought should be clarified, and this necessarily changes the meaning of the work, whatever its artistic merit.

The most important objection to the books is that Le Corbusier cultivated diverse positions and affiliations left and right, that he was therefore confused or contradictory, and effectively left and right or neither. Cohen wrote: 'But he also frequents the left, the Communist Party, he supported the Spanish

99 Jacques Sbriglio, 'Arrêtons de diffamer Le Corbusier, icône audacieuse qui mérite notre salut,' Le Monde, 16 june 2015. Macleod protested that the French authors failed to credit the previous work of the American scholars, yet, Perelman had been writing on Le Corbusier since 1970 and Chaslin credits Fishman, and Macleod et al. If anything it was the Telegraph that made claims the French authors had 'broken the story' But there is a distinction between the Anglo-American writing and the French work, which is far more extreme and militant (particularly Perelman and Jarcy) - there is virtually no comparison.

100 Anonymous, Le projet, la violence et l'histoire: A propos de la mise en accusation de Le Corbusier (Paris, 2015). 
Republicans, is close to the artist Fernand Léger, the Resistance [member] Eugène Claudius-Petit, the Catalan architect Josep Luis Sert, by André Malraux ... He was anti-Boches.' ${ }^{101}$

A related objection is that Le Corbusier was not confused but opportunistic - pursuing whatever movement would accept his plans and hire him. Cohen has the term 'mutual instrumentalisation' for this view, that has dominated the question of Le Corbusier's politics for fifty years. The anonymous author argues that 'Le Corbusier sublimates the question of politics by expressing his interest in all revolutions which undermine the conventions, habits and traditions perceived as obstacles to the implementation of his architectural and urban theories.' ${ }^{102}$ According to Cohen ${ }^{103}$ Le Corbusier's posture is not mere opportunism but a matter of 'seduction', Le Corbusier 'Faced with the leaders to whom he intends to wrest orders, internalizes the discourse, which he takes to his account in an attempt to convince them.... In spite of his friendships for ideologues deeply involved in the politics of Petain, it is in the order of seduction that he will remain in Vichy, without arriving at the political act [itself].104 Chaslin opposes this view of Le Corbusier as 'the worst opportunism': 'I think on the contrary that Le Corbusier was primarily an ideologue, a politician and one of the "leaders" of what in another era would have been called a ... group, a more or less dormant cell ... a militant core that yearned for totalitarianism and that only the confusion of the moment confined it to failure.' 105

The problem with the 'contradictory or confused' and 'opportunistic' arguments is that they dismiss Le Corbusier's thought as non-serious, lacking in integrity or intellectual focus. Any serious student of Le Corbusier including those at the Fondation will agree Le Corbusier was a serious thinker, a person of conviction whose writings expressed his innermost beliefs. Those who protest that Le Corbusier's left activities were elided by the French authors or that make a general claim that Le Corbusier was not a fascist but an ill-fated opportunist have not addressed the specific accusations of fascism ascribed to Le Corbusier by Chaslin and Jarcy. In fact Cohen was quoted saying: the books are 'manipulative but conceding the research was thorough.'106 The question is how to understand left and right in Le Corbusier's thought and action.

\footnotetext{
101 Cohen in Guerrin, 'Le Corbusier, l'architecte de la Cité radieuse,' 4.

102 Anonymous, Le project, la violence et l'histoire.

103 Ibid., 3.

104 My Translation. Jean-Louis Cohen, 'Le Corbusier, fasciste ou séducteur?' Le Monde, 3 June 2015 .

105 Chaslin, Un Corbusier.

106 Samuel, 'Le Corbusier Was “Militant Fascist”.'
} 


\section{Ni droite ni gauche}

Le Corbusier's peculiar political trajectory can only be understood within the development of the historical complex that was French fascism. Perelman contests the principal defence against Le Corbusier's fascism which promulgates 'the idea of a Le Corbusier who first tried Italian Fascism, then rallied to the Popular Front, later to be infatuated by the UssR. In short, we are introduced to a Le Corbusier caught between the often extremist political movements left or right,' 107 that 'the reality [of fascism] is precisely a summation of multiple contradictions, and [each] dependent one on the other.'108

This idea that Le Corbusier couldn't be a fascist because he was also affiliated with the left ignores the complexities of French fascism, and the fact that key French fascists including those in Le Corbusier's circles were equally involved in left and right groups - for the same historical reasons - that fascism evolved in no straightforward way out of the split between the socialist groups in France at the time. The evolution of Le Corbusier's thought mirrored the evolution of French fascism, and the incontrovertible fact that socialism remained a part of it until the end. This history is also compounded by the fact that not only were there a variety of French fascisms; within the matrix of fascism and modernism there are a series of common denominators that receive greater or lesser emphasis depending on whether the orientation within the fascist matrix was left or right; and that this instability meant that, with changing socioeconomic and political conditions, individuals moved in and out of the fascist matrices while retaining some of these common denominators in the process. ${ }^{109}$

The fascism scholar Zeev Sternhell locates the rise of fascist ideology across Europe in the 'anti-materialist' transformation of Marxism that took place in France after the First World War, which opposed classical liberalism and the rationalist ideology of the French Revolution. The first seeds for French

107 Perelman, Le Corbusier, 44.

108 Ibid., 46. Mark Antliff, 'La Cité Française,' 134-70. Fishman, L'utopie urbaine au XXe siècle, 163-88. Perelman, Le Corbusier, 47. After 'Le Corbusier convinced Marshall Petain to give him the Algiers project, in 1942 he co-edited Architecture and Urbanism with [fascists] Charles Trochu, Winter and Paul Boulard, a special issue of Les Cahiers French [whose agenda was] to "prepare and perform the National Revolution defined by Pétain," and "Work on the restoration of French unity, the first condition for the salvation of our fatherland"' Ibid., 52. Perelman identifies Le Corbusier was an antisemite from 1913. Ibid., 39.

109 This thesis is at the heart of Antliff, Avant-Garde Fascism. The chapter on Fascism, Modernism, and Modernity, and the Conclusion, and the chapter on Le Corbusier and Valois are an example of how that dynamic played itself out. 
fascism were planted by Georges Sorel's leftist students who violently rejected the material values of bourgeois capitalism, and decried the Marxist view that socialism issued from class struggle (the emancipation of the proletariat). The Sorelians took over the proletariat and materialist interpretation of historyin this perversion of Marxism that would be branded fascist.

The ideological biography of Sorel, the intellectual father of French fascism, traces an ambiguous intellectual trajectory that can be paralleled to that of Valois and the early Le Corbusier-because they issued from the same historical ground. In 1893, Sorel declared himself a Marxist and a socialist, ${ }^{110}$ writing for the earliest French Marxist journals, but by the turn of the century was active in the 'revisionist debate' and 'crisis of Marxism'. Through his contributions to Hubert Lagardelle's Mouvement socialiste, in 1905, he advanced the theory of revolutionary syndicalism. ${ }^{111}$ In 1906 he published 'Reflections on Violence' in Mouvement socialiste. In 1909-1910 he joined Maurras' Action Française, a prefascist collaboration that would inspire the Cercle Proudhon.

Georges Valois was equally 'ambiguous' - as the leader of the first fascist group in France Le Faisceau, he considered himself the French Mussolini, but later fought for the French resistance, was arrested by the Nazis on 18 May 1944, and died of typhus at the Bergen-Belsen concentration camp in 1945 with the Jews. ${ }^{112}$ Le Corbusier's collaborator in Plans and Prélude Lagardelle was originally a socialist activist founding the Toulouse Marxist journal Socialist Youth in 1895. Like many other contemporary French revolutionary unionists he left the labour movement and developed a tendency towards fascism. In 1926, he joined Le Faisceau. Finally, Marcel Déat was a socialist, Jacques Doriot a communist, and even Mussolini came from the left.

Nobody would accuse Sorel, Valois, Lamour, Lagardelle, Winter or Pierrefeu of being confused, contradictory, or opportunistic for their involvement in left groups. The ambiguity lies in French fascism. The Action Française, Le Faisceau and other fascist groups contained men from both left and right. This situation that was unique to France was best expressed by the phrase ni droite ni gauche (neither right nor left) coined by Valois in his book le fascisme which circulated

\footnotetext{
110 James Jay Hamilton, 'Georges Sorel and the Inconsistencies of a Bergsonian Marxism,' Political Theory 1, no. 3 (1973): 329-340.

111 Francis Neilson, 'Georges Sorel and Syndicalism,' in The Old Freedom (New York: B. W. Huebsch, 1919), 78-94.

112 Allen Douglas, From Fascism to Libertarian Communism: Georges Valois against the Third Republic (Berkeley: University of California Press, 1992), 249.
} 
in French fascist circles in the 1930s. ${ }^{113}$ In Ni Droite ni gauche Sternhell traces the origins of this left-right contradiction to the French revolution and Enlightenment history. He writes that

democratic and liberal France, Jacobin France, nurtured not only the ideology of the French Revolution but also its antithesis ... France like Germany, gave birth at the end of the nineteenth century to a ... cultural nationalism that was sometimes ... of a biological and racial character... From the end of the nineteenth century, this other political tradition launched an all-out attack on liberal democracy ... From the end of the nineteenth century, these two traditions [liberalism and nationalism] fought each other but also coexisted, often in the same work, in the thinking of the same person, independently of the celebrated left-right dichotomy. The traditional concept of a left-right conflict takes into account the realities of the period only very partially, and it often fails to take them into account at all. Neither right nor left, fascism therefore united antibourgeois, antiliberal nationalism, and revolutionary syndicalist thought, each of which joined in reflecting the political culture inherited from eighteenth-century France. ${ }^{114}$

\section{Was There a Conspiracy?}

An interesting question is why these French books appeared in 2015, and why this has turned into a scandal in France, when evidence of Le Corbusier's fascism has been available since 1970. I put these questions to the three authors.

In response, Perelman sent me his publications list on Le Corbusier's politics of the body spanning forty years: 'I did not wait until 2015 to attack radically the political positions, and the written and projected works of Le Corbusier.' But it was only in 2015 that Perelman's work on Le Corbusier was translated into English. As for why all three books came out now, Chaslin replied:

113 Macleod in a letter to Chaslin wrote that 'ni droite, ni gauche was one of Prélude's slogans.' Chaslin, Email from François Chaslin to Simone Brott, 28 January 2017.

114 Zeev Sternhell, Neither Right nor Left: Fascist Ideology in France (Princeton: Princeton University Press, 1986), x, xiii. We can add from Prélude: 'Plus traditionnels que la droite, plus révolutionnaires que la gauche.' But one thing is very specific to the French fascism: the influence of the Action française, catholic, monarchist, antimasonic and violently antisemitic. 
A trigger, ... was the publication in January 2013 of the second of the three volumes of Le Corbusier's letters to his family (1926-1946). It's essential! His fascist connivances appeared [in them] much more blatantly. It was at this point that I undertook to write about this subject since I sent a first version of an article to Arnaud Dercelles [Fondation] on April 12, 2013, who sent it to Rémi Baudouï. A correspondence between us of several pages followed. Already, I was suspected of wanting to 'dirty' the memory of the architect and want[ing] to 'sell paper[s]'.115

Chaslin, says that the problem goes beyond Le Corbusier: 'the collective knowledge we have of the extreme right of France is quite recent, that it is only a short time ago that we consider[ed] the role of architects within these political apparatuses and their situation[s] or action[s] during the Second World War.'116

Jarcy wrote:

there is no evidence of any conspiracy at the Fondation to hide the truth. I would rather say there was a complete denial. People were so fascinated by le Corbusier, so ... enthralled they couldn't see the truth. And now there are some commercial interests. Le Corbusier has almost become a trade mark. So, denial and lack of courage. Also, there is a big denial about how French high classes betrayed the Republic in 1940 and supported Pétain ... It is a very complicated situation, because in 1945 LC came closer to the communist party ... LC lied about his past and made up a new story of his life. And many people benefited from those lies. More generally the history of fascism in architecture and urbanism still has to be written. ${ }^{117}$

115 Email from François Chaslin to Simone Brott, 28 January 2017. Chaslin continues 'Jarcy said during the summer of 2013 that he had accidentally discovered an extract in the Petain dialogue of the Maison des hommes [by Le Corbusier] and had been haunted by it, and in the introduction of his book he describes his sources in 'the writings and letters of the famous architect.' What he did, [was working on the correspondence] with a certain meticulousness, encouraged by what he had, like everyone else discovered at the time of the publication of the second volume of the family correspondence, he endeavored then to draw from their nuances various members of the faisceau, going to the National Archives and having some files opened by the Prefecture of Police.'

116 Ibid.

117 Email from Xavier de Jarcy to Simone Brott, 13 February 2017. 
Perelman concurs:

I do not know if there was a real conspiracy. There was a fierce defence of Le Corbusier through the FLC. The archives of Le Corbusier - which Le Corbusier had surely after the war eliminated a good part! - were sorted and classified in the 1980s-1990s. Perhaps before! . . . Some individuals knew Le Corbusier's links with Vichy. For example, the 'resistant' Eugène Claudius-Petit; or the art historian Pierre Francastel who had very harsh words about Le Corbusier; Malraux, no doubt also, knew the history of this man. Françoise Choay, an architectural critic well known in France and abroad, has never had a clear position on Le Corbusier. [There was] still, great admiration, too much enthrallment to think the reality of Le Corbusier's projects. But for them and many others, we had to forget the past, reconstruct the cities destroyed by the war, move on to something else. You know that Paxton - an American - uncovered the role of Vichy vis-à-vis the Jews in the 1970s, not before. For Le Corbusier, it lasted even longer. But there was a screed of lead which forbade revealing Le Corbusier's past. It was totally taboo ... In this case, everything is very political ... from the end of the war until very recently there was an alliance - a kind of pact of silence - between De Gaulle's supporters and the Communists. This has weighed heavily, among others, on many aspects of French social and political life. ${ }^{118}$

Jarcy's response:

France never admitted it's fascist past. President Chirac admitted only in 1995 the responsibility of the French State in the deportation of the French Jews. But most French historians still don't consider Vichy as a fascist regime. Why? Because that would mean admitting the treason of the French high bourgeoisie. Also, many historians have turned right wing, and they try to say Vichy was not so bad, or to whitewash some collaborationists. ${ }^{119}$

There is another obvious reason for these three books in France, the rise of a new fascism, a fascist wind spreading over Europe today, and the resistance movement that has emerged in relation to it. French writers are now looking to the fascist past for answers to the fascism of the present.

118 Perelman, Email from Marc Perelman to Simone Brott, 25 January 2017.

119 Xavier de Jarcy, Email from Xavier de Jarcy to Simone Brott, 13 February 2017. 